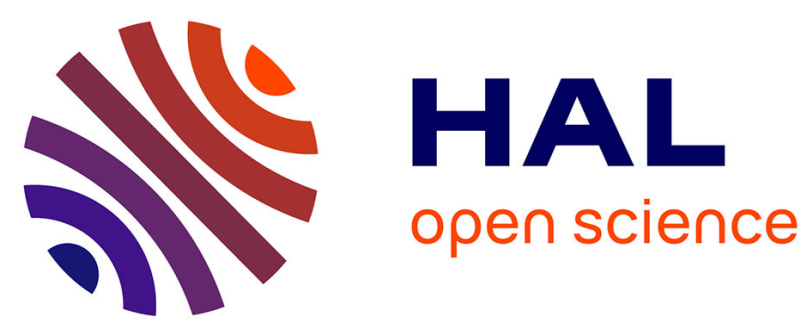

\title{
Influence of cropping system on Fusarium head blight and mycotoxin levels in winter wheat
}

Agnès Champeil, Jean-Francois Fourbet, Thierry Doré, Laure Rossignol

\section{To cite this version:}

Agnès Champeil, Jean-Francois Fourbet, Thierry Doré, Laure Rossignol. Influence of cropping system on Fusarium head blight and mycotoxin levels in winter wheat. Crop Protection, 2004, 23 (6), pp.531537. 10.1016/j.cropro.2003.10.011 . hal-01361990

\section{HAL Id: hal-01361990}

https://hal-agroparistech.archives-ouvertes.fr/hal-01361990

Submitted on 10 Sep 2016

HAL is a multi-disciplinary open access archive for the deposit and dissemination of scientific research documents, whether they are published or not. The documents may come from teaching and research institutions in France or abroad, or from public or private research centers.
L'archive ouverte pluridisciplinaire HAL, est destinée au dépôt et à la diffusion de documents scientifiques de niveau recherche, publiés ou non, émanant des établissements d'enseignement et de recherche français ou étrangers, des laboratoires publics ou privés.

\section{(이)(\$)}

Distributed under a Creative Commons Attribution - NonCommercial - NoDerivatives| 4.0 
3 Influence of cropping system on Fusarium head blight and mycotoxin levels in winter 4 wheat

Champeil A. ${ }^{1}$, Fourbet JF. ${ }^{1}$, Doré T. ${ }^{1}$ and Rossignol L. ${ }^{2}$

1. UMR d'Agronomie INRA/INA P-G, Centre INRA Versailles - Grignon, 78850 Thiverval -

8 Grignon, France. Fax +33130815425 .

9 E mail champeil@grignon.inra.fr, fourbet@grignon.inra.fr, dore@inapg.inra.fr.

${ }^{2}$. Direction Scientifique de la Nutrition Humaine et de la sécurité des Aliments. INRA. 147 rue de l'Université, 75007 Paris.

Email lrossignol@ania.net

\section{Abstract}

In this study, we investigated the effects of various wheat cropping systems on Fusarium head blight severity and mycotoxin (deoxynivalenol, nivalenol, zearalenone) levels. We investigated four wheat-cropping systems: a conventional system, an integrated system, a direct drilling system and an organic system, in fields with natural contamination. The study was carried out over three one-year periods: 1999-2000, 2000-2001 and 2001-2002. The severity of Fusarium head blight and toxin levels differed considerably between years, reflecting climatic effects. In a given year, the severity of Fusarium head blight also differed between cropping systems, with the most severe disease observed in the direct drilling and conventional system plots in 2000. The level of grain contamination by mycotoxins therefore depends on both climate and cropping system. Mycotoxin levels were highest in the year with the highest disease severity: 2000. Contamination levels were highest with the direct drilling system. We were unable to rank the organic and conventional systems, because neither was consistently more contaminated than the other. Moreover, no clear relationship was found between disease severity and levels of contamination with deoxynivalenol, nivalenol or zearalenone under conditions of natural contamination.

Key words

Cropping systems, mycotoxins, deoxynivalenol (DON), Fusarium, Fusarium head blight, wheat 


65

\section{Introduction}

In recent years, the food industry has been faced with several major health crises. This has led to an increase in public concern about food safety. Several mycotoxins cause major safety problems in cereal production (Le Boulc'h et al., 2000). The ingestion of mycotoxins may result in vomiting, reproductive disturbances, leukoencephalomalacia, pulmonary oedema, impairment of the humoral and cellular immune responses, nervous disorders, myocardial hypertrophy and several cancers (Placinta et al., 1999). Some of these toxins are produced before harvest (trichothecenes, fumonisins and zearalenone), whereas others are produced after harvest (ochratoxin A and aflatoxins). Several species of Fusarium are responsible for toxin production before harvest (Maurin and Chenet, 1993). These fungi, together with Microdochium, are responsible for Fusarium head blight, or scab (Cassini, 1970; Ban, 2000). As the deleterious effects of this disease include yield losses of up to 50\% (Atanasoff, 1920; Parry et al., 1995) and the production of various mycotoxins: zearalenone, deoxynivalenol and derivatives, nivalenol, $\mathrm{T}_{2}$-toxin, $\mathrm{HT}_{2}$-toxin and other toxins (Placinta et al., 1999). Climate is thought to be a key determinant of Fusarium head blight (Langseth et al., 1995; Lacey et al., 1999). However, in a given year, neighbouring fields may display different levels of contamination: the cropping system may therefore affect the level of mycotoxin production by Fusarium. The use of fungicides during growth of the wheat crop does not guarantee the absence of toxins in the harvested grain. The entire cropping system must be considered. Several studies have demonstrated effects of soil tillage (Teich and Hamilton, 1985; Dill-Macky and Jones, 2000), preceding crop (Teich and Nelson, 1984; Dill-Macky and Jones, 2000) and wheat genotype (Mesterhazy, 1983; Teich and Hamilton, 1985; Snijders, 1990; Dill-Macky and Jones, 2000) on scab development and/or mycotoxin contamination. However, few studies have analysed both disease severity and mycotoxin contamination. There is also a lack of studies comparing the effects of entire cropping systems rather than aspects of crop management. The aim of this study was to investigate the effects of four cropping systems (conventional, integrated, direct drilling and organic systems) on Fusarium head blight severity and on levels of several mycotoxins in grains. We also tried to correlate both disease severity and levels of contamination with deoxynivalenol, nivalenol and zearalenone levels under conditions of natural contamination.

7

\section{Materials and methods}

\section{Experimental design}


Since 1997, the four cropping systems (conventional, integrated, direct drilling and organic) were compared using "crop X - wheat - crop Y - wheat" crop rotations. We assigned two large plots ( 0.5 ha each) to each cropping system. Each plot was divided in half. On each half (subplot), we organised the rotation such that there was one wheat crop every year on each plot. The conventional system corresponded to intensive agriculture, in which the aim is to achieve the highest net income by maximising yield. The integrated system, in which input levels (and yields) were lower, aimed to maximise net income whilst preserving the environment. In the direct drilling system, crops had been planted without soil tillage and permanent vegetation cover (fescue) had been maintained since 1998-1999. We evaluated this system as an alternative to the integrated system, aiming to achieve the same objectives. No chemical inputs were used in the organic system. Each cropping system was defined in terms of a specific combination of technical choices, each closely related to the others. For example, the choice of cultivar depended on whether a fungicide was to be used. Thus, the cropping systems differed in several aspects: cultivar, tillage, chemical treatments, nitrogen fertilisation, time and density of sowing, and crop sequence. Furthermore, the techniques used within a given cropping system were prone to change from year to year, and depended on climate in particular. As part of a larger study, we compared the agronomic, environmental and economic aspects of the various systems (results not shown). We began to study Fusarium head blight in these experimental plots in 1999/2000. We set up additional treatments in each system to enable us to increase our understanding of the determinants of pathogen attack: the Charger cultivar (the cultivar used in the conventional system) was cropped without fungicide in a subplot of each system.

Over the three-year study period, the preceding crop and fungicide treatment changed each year for each system. In 1999-2000, the fungicide treatments used contained strobularins, whereas in 2000-2001 and 2001-2002, a mixture of strobularins and triazoles was used. Each system remained internally consistent from year to year and the technical details of each system are presented in Table 1. In 2000-2001, sowing conditions were extremely difficult for the direct drilling system due to large amounts of crop residue on the soil surface and high moisture levels in the seedbed (high rainfall during autumn). This led to poor emergence of the wheat crop in this system. We therefore took no samples from the direct drilling system in 2000-2001.

\section{Evaluation of kernel infection by head blight}


103 For each cropping system (and each subplot), we used four randomly selected samples of 25

104 heads to determine disease severity, every week between flowering and physiological 105 maturity of the grain. Disease severity was estimated by determining the percentage of spikelets per head for which at least one third of the external surface of glumes presented symptoms of head blight.

\section{Mycotoxin extraction and analysis}

110 We determined the mycotoxin content of grains from plants sampled at harvest. Plant sampling was based on the 98/53/CE directive, which lays down the sampling procedure for official controls of aflatoxin level. We used this directive as there is no similar text dealing with Fusarium toxins. According to this directive, for plots with yields lower than $1 \mathrm{t}, 10$ samples of $100 \mathrm{~g}$ must be harvested and pooled to give a total sample of $1 \mathrm{~kg}$. We collected 1

$115 \mathrm{~kg}$ grain samples in this manner from each plot. Samples were dried $\left(48 \mathrm{~h}-80^{\circ} \mathrm{C}\right)$ and sent to 116 Qualtech (Vandoeuvre-les-Nancy, France) for testing. In the first two years, we determined 117 the levels of the following mycotoxins: zearalenone, group A and B trichothecenes 118 (diacetoxyscirpenol (DAS), T-2, HT-2, nivalenol (NIV), deoxynivalenol (DON) and derivatives (3-aDON and 15-aDON), fusarenone (FUX), and fumonisins B1 and B2. In the final year, we determined levels of zearalenone, group $\mathrm{A}$ and $\mathrm{B}$ trichothecenes (diacetoxyscirpenol (DAS), monoacetoxyscirpenol (MAS), T-2, HT-2, neosolaniol, T2-triol, nivalenol (NIV), deoxynivalenol (DON) and derivatives (3-aDON and 15-aDON), and fusarenone (FUX). Zearalenone levels were determined with an immunoaffinity highperformance liquid chromatography (HPLC) method, validated by the French norm NF V03110. Fumonisines were determined by HPLC, and trichothecenes by gas chromatographymass spectroscopy (GC-MS), validated by the French norm NF EN ISO/CEI 17025.

\section{Statistical methods}

129 We used the classic ANOVA (one-way analysis of variance) program of the SAS software 130 suite to compare the systems. If a significant $\mathrm{F}$ ratio was obtained $(\alpha<0.05)$, we analysed 131 differences between treatments, using Bonferroni's multiple range test. In this study, there were interactions between year and climate and between year and changes in the cropping system. We therefore chose not to analyse the year effect directly. We focused instead on

134 cropping system effects. ANOVA was carried out with all the individual measurements from each replicate. 


\section{Results}

\section{Disease severity}

140 The severity of Fusarium head blight differed considerably from year to year (Table 2). In 141 2000, severe Fusarium head blight was observed, whereas no symptoms were detected in

142 2001. Disease severity differed significantly between the four cropping systems (Table 2-a) in

143 2000. No difference between the cropping systems was observed in 2001, and in 2002 slight

144 differences were observed between cropping systems but the range of severity observed was 145 limited. In 2000, the direct drilling system displayed the highest level of contamination, 146 followed by the conventional and organic systems. In 2002, the conventional system was the 147 most heavily contaminated. These rankings, in particular that for 2002, which was less clear148 cut, were confirmed by analysis of variance: cropping system was found to have a significant 149 effect on disease severity $(\alpha<0.001)$.

The pattern of disease severity observed in the subsystems was similar to that for the systems as a whole (Table 2-b): contamination was greatest in 2000 , no symptoms were observed in 2001, and 2002 was intermediate. Analysis of the results for 2000 showed that in two systems (conventional and integrated), the subsystem (conventional cultivar used without fungicide) crop was more heavily infected that the adapted system (appropriate cultivar for the system) crop. In contrast, the subsystem and adapted plots were similar for the direct drilling and organic systems. The direct drilling subsystem displayed the highest level of disease severity. Thus, the factors responsible for this high level of disease were presumably not cultivar or fungicide strategy. In contrast, in the other three systems, disease severity seemed to depend on the cultivar and/or fungicide treatment used. In 2001 and 2002, the adapted cropping systems and the subsystems presented similar levels of disease. A plot effect was detected for

162 the subsystem treatment, with plot I more heavily contaminated than plot II. This effect was significant $(\alpha \leq 0.001)$ in 2000 .

\section{The accumulation of mycotoxins in grain}

166 Very little deoxynivalenol (DON) was accumulated in the harvested grain (Table 3-a). The DON content was below the maximum levels $(750 \mu \mathrm{g} / \mathrm{kg})$ cited in provisional European recommendations, for most treatments. The highest levels of accumulation of this toxin were recorded in 2000. In addition to this year effect, a cropping system effect was observed: the

170 direct drilling system (in 2000 and 2002) was systematically and significantly the most 
171 heavily contaminated with this toxin. In 2001, when no samples were available for the direct

172 drilling system, the organic system showed significantly higher levels of DON contamination than the other systems.

The results obtained for the subsystems were very similar (Table 3-b), with the same year and cropping system effects identified. However, the effects of not applying fungicide differed according to the year. DON contamination of the conventional system plots was lower in the absence than in the presence of fungicide in 2000 and 2001, and higher in 2002. Conversely, the Charger cultivar systematically displayed higher levels of contamination than the cultivar used in the organic system. These factors had different effects on mycotoxin contamination. The integrated and direct drilling systems (for which fungicide protection and cultivar varied simultaneously) displayed higher levels of mycotoxin contamination for the subsystems than for the adapted system, with the exception of the direct drilling system in 2000. However, the choice of cultivar and the decision not to treat had a relatively small effect in this system in this year because DON levels consistently exceeded $4000 \mu \mathrm{g} / \mathrm{kg}$ (which is much higher than the maximum level recommended). No significant plot effect was identified.

The fields were also contaminated with nivalenol and zearalenone. Nivalenol contamination differed significantly $(\alpha \leq 0.05)$ between cropping systems in 2001. In all the years studied, nivalenol was detected only in the organic and direct drilling systems. Zearalenone contamination differed considerably from year to year. Zearalenone levels were highest in 2000, with the direct drilling system displaying significantly higher levels of contamination than the other systems $(\alpha \leq 0.05)$ in that year. In 2001, only one field (the organic subsystem) had zearalenone contamination. Zearalenone was not detected in 2002. We detected no other mycotoxins.

\section{The relationship between disease severity and deoxynivalenol accumulation}

198 No relationship between disease severity and mycotoxin levels was observed, between or

199 within years (Figure 1). For example, disease severity was scored at 0\% despite DON levels of 0-600 $\mu \mathrm{g} / \mathrm{kg}$ (years 2001 and 2002). Furthermore, DON levels were low (350 $\mu \mathrm{g} / \mathrm{kg}$ ) on plots in which disease severity score was higher (22\%). even more evident for the subsystems. No disease was observed despite DON levels of 0- 
$1120 \mu \mathrm{g} / \mathrm{kg}$ (years 2001 and 2002) whereas moderate DON contamination $(530 \mu \mathrm{g} / \mathrm{kg}$ ) was recorded for plots with high levels of disease severity (63\%). We also found that there was no relationship between disease severity and mycotoxin levels for nivalenol and zearalenone.

\section{Discussion}

210 Our results demonstrate that Fusarium head blight severity depends mainly on climatic 211 effects. Similar results have been obtained in previous studies (Andersen, 1948; Langseth et 212 al., 1995). However, in years with average or high levels of disease, cropping system affects 213 disease severity. The direct drilling system resulted in the highest disease severity in both 214 years for which results were available. In 2000, the direct drilling system wheat crop followed 215 a maize crop whereas the wheat crop of the integrated system followed oilseed rape. In 2002, 216 the preceding crop was pea in both cases. However, the major difference between the direct 217 drilling and integrated systems was the absence of tillage in the direct drilling system: 218 comparison of these two systems, in 2002, can therefore be used to determine the effect of 219 ploughing in residues. Our results seem to support previous conclusions concerning the 220 effects of land preparation (Teich and Nelson, 1984; Teich and Hamilton, 1985; Dill-Macky and Jones, 2000).

An analysis of agronomic traits (head density, yield, grain protein content, Septoria leaf spot severity, eyespot severity) revealed no clear reason for the plot effect observed for disease severity in 2000. Follow-up of scab severity between flowering and harvest provided a potential clue: disease severity rapidly increased between June 27 and July 3 in plot I, but not in plot II. This increase in disease severity was probably due to heavy rainfall $(21 \mathrm{~mm})$ on July 2nd, after 20 days without precipitation. The experimental field was surrounded by trees and plot II was more protected from rain than plot I, which may have resulted in an edge effect.

This work shows that the Fusarium mycotoxin (deoxynivalenol, nivalenol and zearalenone) content of wheat crops depends on both year and cropping system. These results are consistent with those of previous studies (Teich and Hamilton, 1985; Dill-Macky and Jones, 2000): the direct drilling system generally results in the highest levels of contamination, particularly in years with high levels of disease, such as 2000. Moreover, in 2000, the presence of maize immediately preceding the wheat crop in the rotation of the direct drilling 
Macky and Jones, 2000). It was not possible to rank the other systems because no consistent 240 pattern emerged. In 2000 and 2002, the conventional system was more contaminated than the organic system, whereas the reverse was true for 2001. Higher levels of contamination in the conventional system may result from disease severity being high in that year (which was the case in 2000) or may be due to the fungicide used. Indeed in 2000, we used a mixture of strobularins whereas in 2001 and 2002, we used a mixture of strobularins and triazoles. Strobularins belong to a family of fungicide molecules that are particularly effective against Microdochium strains but some Fusarium strains are limited effectively only by triazole molecules (Maumené et al., 2000). As Microdochium produces no toxins, the application of strobularins does not limit mycotoxin levels. Conversely, it might favour the development of pathogenic strains that produce toxins. Thus, the fungicide treatment used in 2000 might have favoured an increase in mycotoxin levels in the adapted conventional system whereas competition between Fusarium and Microdochium strains may have limited the production of mycotoxins in the organic systems and in the conventional subsystem. In 2000, fungicide application might have resulted in an increase in disease severity in the adapted conventional system, whereas saprophytes might have limited disease development in the adapted organic system. In contrast, in 2002, the absence of fungicide treatment resulted in higher levels of disease severity. In this case, the molecule used was probably more suitable for the infecting pathogenic strains.

The "contaminating complex" effect, operating under natural contamination conditions is probably responsible of the absence of a relationship between disease severity and DON levels. Our results, which are consistent with those of other authors (Liu et al., 1997), are especially important as they relate to moderate or low disease levels, which may conceal significant contamination by mycotoxins. Indeed, in contrast to studies in which crops were artificially contaminated with a single pathogenic strain of Fusarium culmorum, in which such a relationship was found (Teich and Hamilton, 1985; Snijders and Perkowski, 1990), several species of Fusarium and Microdochium are present in the field in natural contamination conditions. Hence, DON levels, disease severity and the relationship between these variables probably depend on the traits of the species present -capacity to produce disease, capacity to produce mycotoxins (deoxynivalenol, nivalenol, zearalenone), capacity to produce symptoms and mycotoxins- together with the time at which contamination occurs,

271 the climatic conditions between the time of contamination and harvest, and the nutritive 
resources that the plant can provide to the pathogenic strains: in other words, the whole cropping system.

\section{Acknowledgements}

This research was funded by the DGAL and by INRA. We would like to thank P. Verger for his suggestion at the start of this study. We would also like to thank Mrs Tanis-Plant and Mrs Jerome for editorial advice and Mr Saulas, Mr Grandeau, Mrs Tanneau and Mr Mille for their contributions to the experimental work.

\section{Literature cited}

Andersen, A. L., 1948. The development of Gibberella zeae head blight of wheat. Phytopathology 38, 595-611.

Atanasoff, D., 1920. Fusarium blight (scab) of wheat and other cereals. Journal of Agricultural Research 20(1), 1-32.

Ban, T., 2000. Studies on the genetics of resistance to Fusarium head blight caused by Fusarium graminearum in wheat. In "International symposium on wheat ingouvernement for scab resistance. Section II. Genetic analysis and gene mapping for scab resistance." (C. Suzhau and Naujing, ed.), pp. 5-10.

Cassini, R., 1970. Facteurs favorables ou défavorables au développement des fusarioses et septorioses du blé. In "Proceeding of meeting of sections cereals and physiology" (Eucarpia, ed.), pp. 271-279, Dijon.

Dill-Macky, R., and Jones, R. K., 2000. The effect of previous crop residues and tillage on Fusarium head blight of wheat. Plant Disease 84, 71-76.

Lacey, J., Bateman, G. L., and Mirocha, C. J., 1999. Effects of infection time and moisture on development of ear blight and deoxynivalenol production by Fusarium spp. in wheat. Annals of Applied Biology 134, 277-283.

Langseth, W., Hoie, R., and Gullord, M., 1995. The influence of cultivars, location and climate on deoxynivalenol contamination of Norwegian oats 1985-1990. Acta Agriculturae Scandinavica 45, 63-67.

Le Boulc'h, V., Bedouret, S., Poyet, V., Barchietto, T., Hazouard, D., De Paepe, I., and Seng, J., 2000. Un test innovant pour contôler la qualité sanitaire des céréales : détection des champignons potentiellement producteurs d'une famille de mycotoxines, les 
trichothécènes. In "AFPP - $6^{\text {ème }}$ conférence internationale sur les maladies des plantes", Vol. 1, pp. 451-458, Tours, France.

Liu, W., Langseth, W., Skinnes, H., Elen, O. N., and Sundheim, L., 1997. Comparison of visual head blight ratings, seed infection levels, and deoxynivalenol production for assessment of resistance in cereals inoculated with Fusarium culmorum. European Journal of Plant Pathology 103, 589-595.

Maumené, C., Leuillet, M., Caron, D., and Henriot, F., 2000. Incidence des fongicides et de la variété sur le risque de contamination du blé tendre par le déoxynivalénol (DON) en france : premiers résultats. In "AFPP - $6^{\text {ème }}$ conférence internationale sur les maladies des plantes", Vol. 1, pp. 459-466, Tours, France.

Maurin, N., and Chenet, I., 1993. Espèces de Fusarium présentes dans les cultures de céréales en France. Phytoma 453, 20-22.

Mesterhazy, A., 1983. Breeding wheat for resistance to Fusarium graminearum and Fusarium culmorum. Z. Pflanzenzüchtg - Plant Breeding 91, 295-311.

Parry, D. W., Jenkinson, P., and McLeod, L., 1995. Fusarium ear blight (scab) in small grain cereals - a review. Plant Pathology 44, 207-238.

Placinta, C. M., D'Mello, J. P. F., and Macdonald, A. M. C., 1999. A review of worldwide contamination of cereal grains and animal feed with Fusarium mycotoxins. Animal Feed Science and Technology 78, 21-37.

Snijders, C. H. A., 1990. Fusarium head blight and mycotoxin contamination of wheat, a review. Nertherland Journal of Plant Pathology 96, 187-198.

Snijders, C. H. A., and Perkowski, J., 1990. Effects of head blight caused by Fusarium culmorum on toxin content and weight of wheat kernels. Phytopathology 80, 566-570.

Teich, A. H., and Hamilton, J. R., 1985. Effect of cultural practices, soil phosphorus, potassium, and $\mathrm{pH}$ on the incidence of Fusarium head blight and deoxynivalenol levels in wheat. Applied and Environmental Microbiology 79(6), 1429-1431.

Teich, A. H., and Nelson, K., 1984. Survey of Fusarium head blight and possible effects of cultural practices in wheat fields in Lambton County in 1983. Canadian Plant Disease Survey 64(1), 11-13. 
336 Table 1a: Principal traits of the four adapted cropping systems over the three years. Mixture 1:

337 Somme, Malacca, Renan, Camp Remy; Mixture 2: Somme, Malacca, Virtuose, Apache;

338 Mixture 3: Charger, Virtuose, Renan, Paindor.

340 The organic system received no nitrogen fertilisation in 1999-2000 and 2000-2001.

341 In the 2000-2001 study period, the wheat crop in the organic system was sown in January

342 2001. We planned to sow this crop in November, but incessant rain between October 2000

343 and January 2001 rendered this impossible.

Table 1b: Principal traits of the four cropping subsystems over the three years. No fungicide 346 treatment, cultivar Charger.

348 The organic system received no nitrogen fertilisation in 1999-2000 and 2000-2001.

349 In the 2000-2001 study period, the wheat crop in the organic system was sown in January 350 2001. We planned to sow this crop in November, but incessant rain between October 2000 351 and January 2001 rendered this impossible.

Table 2: Comparison of disease severity in the four cropping systems during three years.

354 Charger is the cultivar used in the adapted conventional system.

356 Table 3: Comparison of deoxynivalenol accumulation $(\mu \mathrm{g} / \mathrm{kg})$ for four cropping systems over 357 three years. nd: not detected $(30 \mu \mathrm{g} / \mathrm{kg}$ is the detection limit).

Figure 1: Relationship between disease severity and deoxynivalenol accumulation in four 360 cropping systems over three years. C conventional, I integrated, DD direct drilling, O organic. 36100 2000, 01 2001, 022002 ( ) Adapted cropping system, ( $\square$ ) Subsystem: cultivar Charger 362 without fungicide 
Table 1(a)

\begin{tabular}{|c|c|c|c|c|c|c|c|c|}
\hline $\begin{array}{l}\text { Adapted } \\
\text { system }\end{array}$ & $\begin{array}{l}\text { Sowing } \\
\text { time }\end{array}$ & $\begin{array}{c}\text { Flowering } \\
\text { time }\end{array}$ & $\begin{array}{l}\text { Harvest } \\
\text { time }\end{array}$ & $\begin{array}{c}\text { Nitrogen } \\
\text { (kg/ha) }\end{array}$ & $\begin{array}{l}\text { Seed rate } \\
\left(\text { seeds } / \mathrm{m}^{2}\right)\end{array}$ & Fungicide treatment & Cultivar & $\begin{array}{c}\text { Previous } \\
\text { crop }\end{array}$ \\
\hline Conventional & $11 / 10 / 99$ & $23 / 05 / 00$ & \multirow{4}{*}{ 03/08/00 } & 247 & 260 & \multirow{3}{*}{$\begin{array}{c}\text { Strobularins } \\
\text { (azoxystrobin) }\end{array}$} & Charger & Oilseed \\
\hline Integrated & & & & 197 & 165 & & \multirow{3}{*}{$\begin{array}{l}\text { Mixture } \\
\quad 1\end{array}$} & Rape \\
\hline $\begin{array}{l}\text { Direct } \\
\text { drilling }\end{array}$ & 27/10/99 & $25 / 05 / 00$ & & 197 & 220 & & & $\begin{array}{l}\text { Maize } \\
\text { with } \\
\text { fescue }\end{array}$ \\
\hline Organic & $10 / 11 / 99$ & $30 / 05 / 00$ & & 0 & 450 & None & & $\begin{array}{l}\text { Oilseed } \\
\text { Rape }\end{array}$ \\
\hline Conventional & 04/10/00 & $28 / 05 / 01$ & \multirow{4}{*}{$30 / 07 / 01$} & 249 & 260 & $\begin{array}{l}\text { Mixture of strobularins } \\
\text { (azoxystrobin), triazoles } \\
\text { (tebuconazole), } \\
\text { prochloraze, cyprodinil }\end{array}$ & Charger & $\begin{array}{l}\text { Oilseed } \\
\text { Rape }\end{array}$ \\
\hline Integrated & $24 / 10 / 00$ & \multirow[b]{2}{*}{ 01/06/01 } & & 201 & 165 & \multirow{2}{*}{$\begin{array}{c}\text { Strobularins } \\
\text { (azoxystrobin), } \\
\text { cyprodinil }\end{array}$} & \multirow[b]{2}{*}{$\begin{array}{l}\text { Mixture } \\
\quad 1\end{array}$} & \\
\hline $\begin{array}{l}\text { Direct } \\
\text { drilling }\end{array}$ & $25 / 10 / 00$ & & & 167 & 220 & & & $\begin{array}{l}\text { Maize } \\
\text { with } \\
\text { fescue }\end{array}$ \\
\hline Organic & $17 / 01 / 01$ & $27 / 06 / 01$ & & 0 & 450 & None & $\begin{array}{c}\text { Mixture } \\
3\end{array}$ & $\begin{array}{l}\text { Spring } \\
\text { lupin }\end{array}$ \\
\hline Conventional & 05/10/01 & 06/06/02 & $29 / 07 / 02$ & 208 & 260 & $\begin{array}{l}\text { Mixture of strobularins } \\
\text { (azoxystrobin), triazoles } \\
\text { (fluquinconazole, } \\
\text { epoxinazole), } \\
\text { prochloraze }\end{array}$ & Charger & Pea \\
\hline Integrated & $17 / 10 / 01$ & $23 / 05 / 02$ & & 131 & 165 & Mixture of strobularins & & \\
\hline $\begin{array}{l}\text { Direct } \\
\text { drilling }\end{array}$ & $26 / 10 / 01$ & $25 / 05 / 02$ & $30 / 07 / 02$ & 141 & 220 & $\begin{array}{c}\text { (azoxystrobin), triazoles } \\
\text { (epoxinazole) }\end{array}$ & 2 & \\
\hline Organic & $31 / 10 / 01$ & $23 / 05 / 02$ & & 54 & 450 & None & Apache & \\
\hline
\end{tabular}

367 
Table 1(b)

\begin{tabular}{|c|c|c|c|c|c|c|c|c|}
\hline Subsystem & $\begin{array}{l}\text { Sowing } \\
\text { time }\end{array}$ & $\begin{array}{c}\text { Flowering } \\
\text { time }\end{array}$ & $\begin{array}{l}\text { Harvest } \\
\text { time }\end{array}$ & $\begin{array}{l}\text { Nitrogen } \\
\text { (kg/ha) }\end{array}$ & $\begin{array}{l}\text { Seed rate } \\
\left(\text { seeds } / \mathrm{m}^{2}\right)\end{array}$ & $\begin{array}{l}\text { Fungicide } \\
\text { treatment }\end{array}$ & Cultivar & $\begin{array}{c}\text { Previous } \\
\text { crop }\end{array}$ \\
\hline Conventional & $11 / 10 / 99$ & $23 / 05 / 00$ & \multirow{4}{*}{ 03/08/00 } & 247 & 260 & \multirow{4}{*}{ None } & \multirow{4}{*}{ Charger } & Oilseed \\
\hline Integrated & & & & 197 & 165 & & & Rape \\
\hline $\begin{array}{l}\text { Direct } \\
\text { drilling }\end{array}$ & 27/10/99 & $25 / 05 / 00$ & & 197 & 220 & & & $\begin{array}{c}\text { Maize } \\
\text { with } \\
\text { fescue }\end{array}$ \\
\hline Organic & $10 / 11 / 99$ & $30 / 05 / 00$ & & 0 & 450 & & & $\begin{array}{l}\text { Oilseed } \\
\text { Rape }\end{array}$ \\
\hline Conventional & $04 / 10 / 00$ & $28 / 05 / 01$ & \multirow{3}{*}{$30 / 07 / 01$} & 249 & 260 & \multirow{3}{*}{ None } & \multirow{3}{*}{ Charger } & Oilseed \\
\hline Integrated & $24 / 10 / 00$ & $01 / 06 / 01$ & & 201 & 165 & & & Rape \\
\hline Organic & $17 / 01 / 01$ & $27 / 06 / 01$ & & 0 & 450 & & & $\begin{array}{l}\text { Spring } \\
\text { lupin }\end{array}$ \\
\hline Conventional & $05 / 10 / 01$ & $06 / 06 / 02$ & $29 / 07 / 02$ & 208 & 260 & \multirow{4}{*}{ None } & \multirow{4}{*}{ Charger } & \multirow{4}{*}{ Pea } \\
\hline Integrated & $17 / 10 / 01$ & $06 / 06 / 02$ & & 131 & 165 & & & \\
\hline $\begin{array}{l}\text { Direct } \\
\text { drilling }\end{array}$ & $26 / 10 / 01$ & 06/06/02 & $30 / 07 / 02$ & 141 & 220 & & & \\
\hline Organic & $31 / 10 / 01$ & $06 / 06 / 02$ & & 54 & 450 & & & \\
\hline
\end{tabular}


Table 2

(a) Adapted cropping

system (b) Subsystem:

Charger without fungicide

\begin{tabular}{lccccccc}
\hline Cropping systems & Plots & 2000 & 2001 & 2002 & 2000 & 2001 & 2002 \\
\hline Conventional & I & $24 \%$ & $0 \%$ & $3 \%$ & $63 \%$ & $0 \%$ & $4 \%$ \\
\cline { 2 - 7 } & II & $23 \%$ & $0 \%$ & $1 \%$ & $22 \%$ & $0 \%$ & $1 \%$ \\
\hline Integrated & I & $6 \%$ & $0 \%$ & $0 \%$ & $28 \%$ & $0 \%$ & $2 \%$ \\
\cline { 2 - 7 } & II & $8 \%$ & $0 \%$ & $0 \%$ & $17 \%$ & $0 \%$ & $2 \%$ \\
\hline Direct Drilling & I & $34 \%$ & $\cdot$ & $1 \%$ & $47 \%$ & $\cdot$ & $5 \%$ \\
\cline { 2 - 7 } & II & $38 \%$ & $\cdot$ & $0 \%$ & $23 \%$ & $\cdot$ & $3 \%$ \\
\hline Organic & I & $5 \%$ & $0 \%$ & $0 \%$ & $2 \%$ & $0 \%$ & $5 \%$ \\
\cline { 2 - 7 } & II & $22 \%$ & $0 \%$ & $0 \%$ & $1 \%$ & $0 \%$ & $3 \%$ \\
\hline
\end{tabular}


373 Table 3

(a) Adapted cropping

system (b) Subsystem:

Charger without fungicide

\begin{tabular}{lccccccc}
\hline Cropping systems & Plots & 2000 & 2001 & 2002 & 2000 & 2001 & 2002 \\
\hline Conventional & I & 1230 & 120 & 150 & 490 & nd & 310 \\
\cline { 2 - 7 } & II & 860 & nd & 380 & 530 & 60 & 340 \\
\hline Integrated & I & 430 & nd & nd & 530 & nd & 310 \\
\cline { 2 - 7 } & II & 270 & nd & 280 & 320 & 160 & 340 \\
\hline Direct Drilling & I & 7420 & nd & 400 & 4230 & $\cdot$ & 800 \\
\cline { 2 - 8 } & II & 9100 & nd & 600 & 8220 & $\cdot$ & 1100 \\
\hline Organic & I & 230 & 430 & 100 & 370 & 1120 & 600 \\
\cline { 2 - 8 } & II & 350 & 370 & 110 & 670 & 1020 & 600
\end{tabular}

374 
$375 \quad$ Figure 1

376

377

378

379

380

381

382

383

384

385

386

387

388

389

390

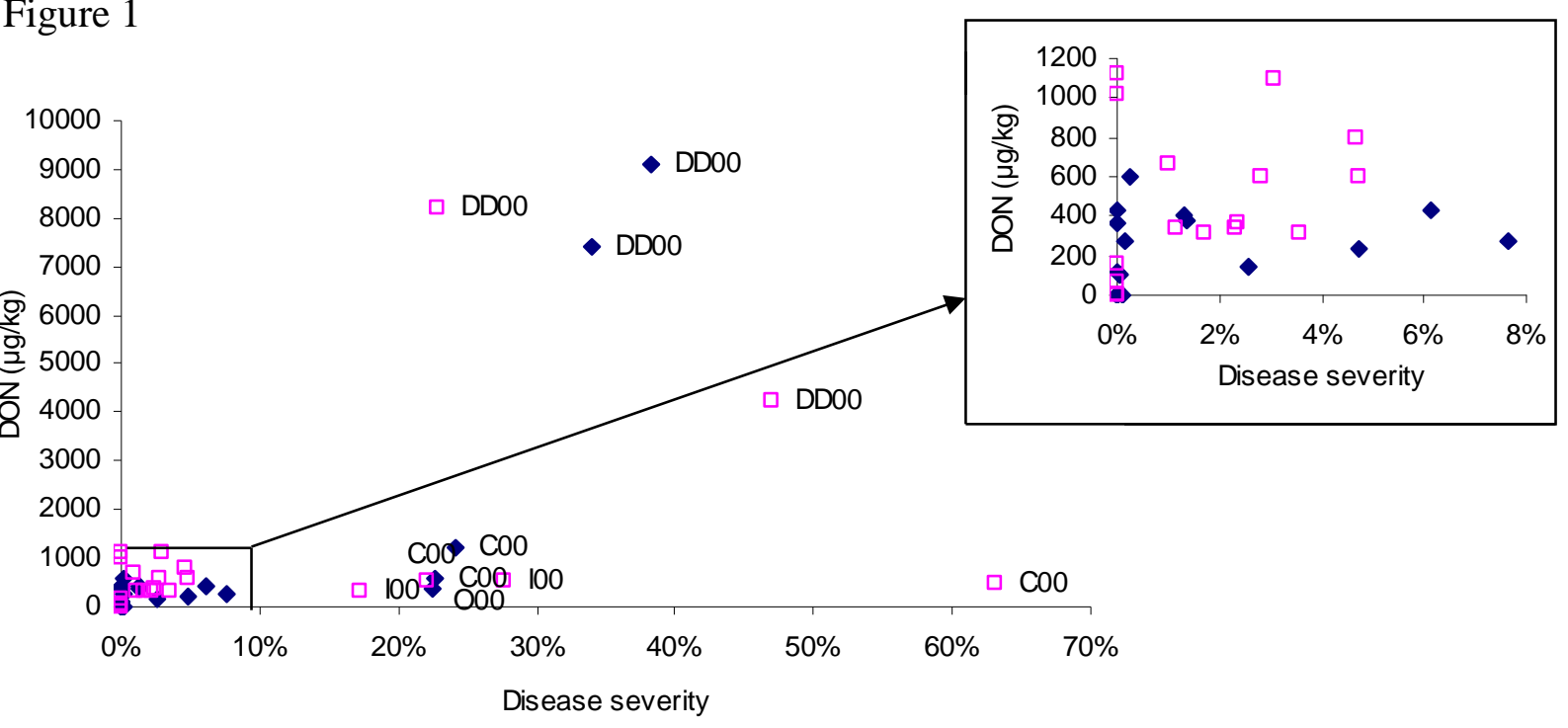

391 